\title{
Modal Sosial-Multikultural Pesantren dalam Membangun Harmoni Sosial Umat Beragama
}

\author{
Sauqi Futaqi* \\ Universitas Islam Darul 'Ulum Lamongan, Indonesia \\ Jl. Airlangga No. 03, Merjoyo, Sukodadi, Kec. Lamongan, Kabupaten Lamongan, Jawa \\ Timur 62253 \\ Email: sauqifutaqi@unisda.ac.id
}

\begin{abstract}
The study aims to find out the social capital that is owned and utilized by the Pesantren Al-Qodir. Social capital is also related to the problem of diversity, which researchers the term as social-multicultural capital. By using qualitative phenomenological research, the results show that there are two areas/sources of social-multicultural capital, namely internal and external capital. Internal capital includes the diversity of students and socio-cultural values that are built up in pesantren. The internal capital is bonding (binding/uniting). External capital is related to multicultural networks and building trust social trust for pesantren and diverse external communities. This external capital displays the type of bridging. The existence of socio-multicultural capital makes pesantren have the ability and make a real contribution to building social harmony, especially for religious communities.
\end{abstract}

Keywords: Pesantren, Social Capital, Multicultural, Social Harmony

\begin{abstract}
Abstrak: Kajian ini bertujuan untuk membahas modal sosial yang dimiliki dan didayagunakan oleh pesantren Al-Qodir. Modal sosial tersebut juga berkaitan dengan masalah keragaman, yang diistilahkan peneliti sebagai modal sosial multikultural. Dengan menggunakan riset kualitatif fenomenologis, hasil riset menunjukkan adanya dua area/sumber modal sosial-multikultural, yakni modal internal dan eksternal. Modal internal mencakup keragaman santri dan nilai sosial-budaya yang terbangun didalamnya. Modal internal ini bersifat bonding (mengikat/mempersatukan). Modal eksternal berkaitan dengan jejaring multikultural dan terbangunnya kepercayaan (social trust) bagi pesantren dan komunitas eksternal yang beragam. Modal eksternal ini menampilkan tipe bridging (menjembatani). Adanya modal sosial-multikultural tersebut menjadikan pesantren ini memiliki kemampuan dan berkontribusi nyata dalam pembangunan harmoni sosial, terutama bagi umat beragama.
\end{abstract}

Kata Kunci: Pesantren, Modal Sosial, Multikultural, Harmoni Sosial 


\section{PENDAHULUAN}

Studi tentang modal sosialmultikultural sebenarnya merupakan kajian lebih lanjut dari beberapa studi mengenai modal sosial. Penekanannya terletak pada paradigma yang menganggap bahwa keragaman merupakan modal sosial yang berharga. Dengan menjadikan keragaman sebagai modal sosial, studi ini juga menaruh perhatian yang besar terhadap jejaring sosial yang diperluas, tidak hanya pada komunitas internal pesantren, lintas pesantren, dan lintas komunitas muslim, tetapi juga komunitas eksternal yang beragam secara kultur dan agama.

Ide tentang kajian modal sosialmultikultural tersebut muncul ketika peneliti melihat fenomena yang terjadi di Pesantren Al-Qodir, Cangkringan, Sleman. Pertama, pesantren tersebut merupakan komunitas pendidikan Islam yang didalamnya terbangun relasi sosialbudaya yang unik. Pesantren tersebut ditempati oleh santri yang beragam dan mereka dapat meleburkan diri dalam satu identitas kesantrian. Di tengah keragaman santri tersebut, terbangun relasi sosial lintas budaya, bahasa, etnis, tingkat pendidikan, paham keagamaan, dan status sosial dalam suasana yang harmonis. Kedua, pesantren ini juga menjalin kontak sosial dengan masyarakat sekitar, komunitas lintas agama, dan komunitas sosial yang lain di luar pesantren. Kontak sosial yang bersifat lintas tersebut membentuk satu pola hubungan dan dalam hal tertentu bisa disebut sebagai jejaring multikultural.

Relasi pesantren dan masyarakat tersebut memiliki jangkauan yang berbeda. Ada yang menciptakan batas fisik yang tegas dengan dikelilingi tembok pemisah untuk membedakan diri dengan aktivitas masyarakat. Namun, ada juga pesantren yang membaur dengan masyarakat tanpa batas fisik yang tegas. Pesantren Al-Qodir merupakan tipe pesantren yang kedua. Pesantren AlQodir berdiri di tengah-tengah masyarakat desa Wukirsari tanpa adanya tembok pemisah dan relasinya dengan masyarakat sekitar juga berjalan secara terbuka. Masyarakat sering berkunjung ke pesantren, sedangkan santri terbiasa berhubungan dan berkomunikasi dengan mereka. Keduanya bisa saling akrab karena intensitas perjumpaan yang hampir terjadi setiap hari.

Fenomena relasi sosial tersebut menunjukkan bahwa pesantren Al-Qodir tidak hanya memiliki modal sosial monobudaya dan mono-agama, melainkan melintasi batas-batas kultur dan agama. Bahkan, pesantren tersebut seringkali membangun jejaring dengan komunitas lintas agama, komunitas seni lokal (jathilan, wayang, dan lainnya), dan komunitas sosial lainnya. Dari semua agama yang ada di Indonesia, termasuk penganut aliran kepercayaan, pesantren pernah menjalin hubungan dengan mereka, baik secara struktural maupun kultural.

Bangunan relasi sosial internal dan eksternal pesantren di atas secara tidak langsung memperlihatkan adanya satu bentuk modal sosial yang bisa disebut dengan istilah modal sosial-multikultural. Artinya, modal sosial pesantren tidak hanya terbatas pada identitas kesantrian atau pesantren, kelompok, agama, maupun kultur tertentu, melainkan multikultural. Sebagai modal sosialmultikultural, relasi dan jejaring tersebut tidak hanya memperkaya modal pesantren, tetapi juga turut berkontribusi dalam membangun harmoni sosial umat beragama.

\section{KONSEP TEORI \\ Modal Sosial-Multikultural}

Kajian tentang modal sosialmultikultural bisa dijelaskan dari teori modal sosial (social capital) sebagaimana yang banyak dibicarakan oleh para teoritikus sosial. Teoritikus sosial yang 
sering menjadi rujukan tentang modal sosial antara lain Pierre Bourdieu, James Colemen, Robert Putnam, dan Nan Lin. Gagasan utama modal sosial adalah bahwa jaringan sosial adalah aset berharga. Jaringan memberikan dasar bagi kohesi sosial karena mereka memungkinkan orang untuk bekerja sama satu sama lain untuk saling menguntungkan (Field).

Modal sosial oleh Bourdieu diartikan sebagai jumlah sumber daya, aktual atau potensial, yang diperoleh individu atau kelompok melalui jaringan relasi yang bertahan lama dari perkenalan dan pengakuan bersama, baik yang terlembagakan maupun kurang terlembagakan (Bourdieu). Bourdieu memandang modal sosial lebih kepada jaringan relasi yang terbangun secara secara individu maupun kelompok, baik institusional maupun non-institusional.

Hampir sama dengan Bourdieu, Colemen melihat modal sosial sebagai representasi sumber daya yang didalamnya mengandung relasi timbal balik yang saling menguntungkan. Modal sosial ini menampilkan tiga bentuk modal, yakni obligasi dan ekspektasi, saluran informasi, dan norma sosial (Bourdieu). Begit juga Putnam (1993), dalam John Field, modal sosial mengacu pada fitur organisasi sosial seperti kepercayaan, norma, dan jaringan yang dapat meningkatkan efisiensi sosial melalui aksi yang terkoordinasi (Field). Baik Bourdieu, Colemen, maupun Putnam pada dasarnya sama-sama menekankan modal sosial pada relasi-relasi atau jaringan yang saling menguntungkan, meskipun terdapat sedikit perbedaan, terutama dalam mengategorikan komponen modal sosial.

Teori modal sosial tersebut bisa dipahami lebih komprehensif dengan melihat komponen-kompenennya. Merangkum dari beberapa teori modal sosial yang dikemukakan para ahli, Usman menyimpulkan beberapa komponen modal sosial. Pertama, dimensi struktural yang mencakup ikatan sosial dan jejaring. Kedua, dimensi kultural yang mencakup kepercayaan sosial (social trust) dan pertukaran sosial (Usman).

Modal sosial juga bisa dianalisis berdasarkan tipenya. Dalam hal ini, peneliti menggunakan dua tipe yang dikemukakan Putnam, yakni bonding social capital dan bridging social capital. Modal sosial dengan tipe bonding merupakan modal sosial dalam konteks ide, relasi dan perhatian yang berorientasi ke dalam (inward looking). Sedangkan, modal sosial dalam bentuk bridging bersifat inklusif dan berorientasi ke luar (outward looking). Tipe bonding menyatukan orang-orang satu sama lain dalam hal-hal penting (etnis, usia, jenis kelamin, kelas sosial, dan sebagainya), sedangkan tipe bridging mengacu pada jaringan sosial yang menyatukan orangorang yang tidak sama satu sama lain. Ini adalah perbedaan penting, karena efek eksternal dari jaringan bridging cenderung positif, sementara jaringan ikatan (terbatas dalam relung sosial tertentu) berada pada risiko lebih besar untuk menghasilkan eksternalitas negatif. Tentu saja bukan untuk mengatakan bahwa kelompok bonding pasti buruk; memang, bukti menunjukkan bahwa kebanyakan dari kita mendapatkan dukungan sosial dari bonding daripada bridging (Putnam).

Berdasarkan teori modal sosial di atas, maka modal multikutural bisa dianalisis dengan modal sosial. Hal ini didasarkan pada argumentasi bahwa ikatan sosial, jejaring sosial, social trust, dan pertukaran sosial lintas kultural merupakan modal sosial-multikultural yang berharga. Modal sosialmultikultural ini juga bisa dibilang merupakan pengembangan lebih lanjut dari studi modal sosial. Perbedaanya terletak pada perhatiannya yang besar terhadap jejaring sosial yang diperluas, 
tidak hanya pada komunitas internal pesantren, antar pesantren, dan antar komunitas muslim, tetapi juga komunitas eksternal yang beragam secara kultur dan agama. Modal sosial tidak hanya untuk menjaga kohesi sosial di lingkungan pesantren, tetapi juga untuk menjembatani berbagai berbagai perbedaan di masyarakat. Pesantren juga tidak hanya konsentrasi pada stabilitas sosial internal pesantren, tetapi juga melakukan aksi-aksi sosial multikultural di masyarakat.

\section{Harmoni Sosial}

Istilah harmoni sosial seringkali didengar dalam kosakata sehari-hari, terutama untuk menggambarkan suasana ketentraman. Namun, istilah ini perlu dijelaskan secara teoritis makna hakiki dari harmoni sosial. Konsep harmoni dalam beberapa literatur sebenarnya mencakup makna yang luas. Fabio dan Tsuda ketika mengkaji konsep ini dalam kajian Barat dan Timur memiliki fitur yang luas. Berdasarkan kajiannya, fitur utama keharmonisan sosial adalah dialog atau komunikasi, toleransi, koeksistensi dan pengembangan, yang didasarkan pada pluralisme, keragaman, kompetisi, dan kreativitas. Pada intinya adalah kemampuan untuk tetap bersama sambil menerima perbedaan upaya untuk menemukan kesamaan tanpa membuang identitas yang berbeda. Keharmonisan sosial meliputi beberapa tahap: harmoni yang meliputi keselarasan antara semua kelompok etnis dan budaya (antara budaya dominan dan subkultur serta antara budaya berbagai kelas sosial); harmoni dalam rasa hormat terhadap suatu negara atau budaya; keharmonisan antar berbagai agama; dan harmoni antara Manusia dan Alam (Di Fabio and Tsuda).

Harmoni juga mencakup berbagai tingkatan: Di dalam individu, antara individu, antara manusia dan dunia/alam semesta. Di dalam individu, harmoni mengacu pada orang dan proses menyelaraskan berbagai bagian tubuh, pikiran, hati, dan berbagai tujuan hidup dalam keseluruhan organik yang berfungsi dengan baik. Antara individu, harmoni berfokus pada individu-individu, karena harmoni dapat diwujudkan antara individu-individu pada tingkat yang berbeda: Keluarga, komunitas, bangsa, dan dunia. Harmoni antara manusia dan alam semesta mengacu pada hubungan khusus termasuk keharmonisan masyarakat manusia dan dunia dengan tujuan akhir untuk mencapai harmoni besar di seluruh kosmos (Di Fabio and Tsuda).

Dalam perspektif orang Jawa, ada penelitian menarik yang dilakukan oleh Sri Lestari, et.al. Harmoni bagi orang jawa bisa dipahami melalui konsep "Rukun". Dalam penelitianya tentang "rukun" bagi orang Jawa, "Rukun" atau harmoni dicirikan dengan kemampuan menjaga keterhubungan, keselarasan, dan mengelola konflik serta bersikap peduli (Lestari and Faturochman).

Kedua teori tersebut setidaknya menunjukkan bahwa hamoni sosial merupakan kondisi sosial dimana terjalin keterhubungan, keselarasan, saling berdialog, saling toleransi, koeksistensi dan pengembangan, yang didasarkan pada keragaman, kompetisi, dan kreativitas. Ia tidak hanya terjadi pada level antar individu, tetapi juga antar kelompok dan antara manusia dengan alam semesta. Harmoni sosial juga bukan merupakan produk jadi, melainkan proses terus menerus (harmonisasi) yang diwujudkan dalam kehidupan masyarakat.

\section{METODE PENELITIAN}

Penelitian ini mengkaji modal atau aset sosial yang berkaitan dengan multikultural di Pesantren Al-Qodir yang terletak di dusun Tanjung, desa Wukirsari, kecamatan Cangkringan, kabupaten Sleman, Yogyakarta. Dengan 
pendekatan kualitatif fenomenologis, peneliti dapat lebih memahami apa yang dipikirkan dan dialami oleh komunitas pesantren. Agar dapat memahami makna fenomena yang dialami langsung oleh informan, peneliti berusaha mendekat secara fisik dan psikologis fenomena yang dikaji (Patton). Sementara pendekatan yang digunakan adalah observasi, wawancara (in-depth interview), dan dokumen-dokumen kualitatif.

Kegiatan observasi dilakukan terutama pada aktivitas sehari-hari Kiai, ustadz, dan santri di pesantren, khusunya terkait relasi sosial dan nilai-nilai yang terbangun secara internal. Peneliti juga mengamati orang-orang atau komunitas lintas agama dan budaya di luar pesantren yang menjalin relasi dan kerjasama, serta kegiatan-kegiatan yang dilakukan bersama. Selain itu, peneliti juga melakukan wawancara dengan Kiai, pengurus pesantren, ustadz, dan santri, serta beberapa anggota komunitas lain. Untuk memperkuat data, peneliti juga melakukan wawancara dengan komunitas lintas agama, seperti FPUB, Orang Muda Katholik (OMK), komunitas gereja, dan lainnya sebagai mitra kerjasama pesantren dalam menyelenggarakan kegiatan sosial- multikultural. Total informan yang diwawancari berjumlah 16, dari internal pesantren 13 orang dan 3 orang dari komunitas di luar pesantren. Dokumen-dokumen yang terkait juga akan menjadi fokus peneliti. Dokumen tersebut diantaranya profil pesantren, foto dan agenda kegiatan multikultural, dan dokumen lain yang terkait.

Data yang sudah terkumpul tersebut dianalisis menggunakan langkah-langkah yang ditawarkan oleh Miles, Hubermen, dan Saldana (B. Miles et.al.). Langkah pertama disebut kondensasi data (data condensation), tahapan yang akan dilakukan dengan cara menyeleksi, memfokuskan, menyederhanakan, mengabstraksi, dan mentransformasi dari data yang terkumpul (catatan observasi, transkip wawancara, dan dokumen) (B.Miles et.al.). Semua data yang terkumpul terkait modal sosialmultikultural tanpa direduksi, melainkan perlu seleksi, fokus, dan penyederhanaan sebelum data tersebut disajikan untuk dianalisis lebih lanjut. Langkah kedua berupa penyajian data, yakni proses mengorganisasikan informasi tidak hanya dalam bentk analisis naratif, melainkan juga dibuat matrik, grafik, jaringan dan bagan, untuk menghindarkan peneliti dari kesalahan dalam menarik kesimpulan (B.Miles et.al.). Langkah ketiga adalah penarikan kesimpulan (drawing and verifying conclusions). Mulai dari pengumpulan data, peneliti mulai mencari makna dengan mencatat pola, penjelasan, alur sebab akibat, dan proposisi. Dalam menginterpretasi data, peneliti akan mencoba membandingkan antara hasil penelitian dengan informasi yang berasal dari literatur atau teori. Tiga proses analisis data kualitatif tersebut merupakan kegiatan yang jalin-menjalin pada saat sebelum, selama, dan sesudah pengumpulan data.

\section{HASIL DAN PEMBAHASAN \\ Pesantren Al-Qodir dan Modal Sosial- Multikultural}

Pondok pesantren Al-Qodir mulai dirintis oleh KH. Masrur Ahmad sekitar tahun 1980 dan baru dibangun gedung santri pada tahun 1990. Pesantren yang terletak di dusun Tanjung, desa Wukirsari, kecamatan Cangkringan, Sleman Yogyakarta tersebut merupakan tipe pesantren yang tetap mempertahankan tradisi kitab-kitab klasik (kitab kuning) sebagai inti pendidikan di pesantren. Disamping pengajaran kitab-kitab klasik, pesantren Al-Qodir juga merasa ikut bertanggungjawab dalam pembangunan moral masyarakat. Di bidang yang lain, pesantren Al-Qodir juga terpanggil untuk melestarikan tradisi dan kesenian tradisional seperti Wayang, Jathilan, 
Ketoprak, dan lainnya yang sudah lama tumbuh di masyarakat lereng Merapi. Salah satunya adalah dengan cara secara rutin menggelar festival Jathilan, Wayang, Ketoprak, dan lainnya yang diikuti oleh beragam kelompok yang berada di sekitar kawasan lereng Merapi. Lantaran sering menggelar kegiatan lomba tersebut, $\mathrm{KH}$. Masrur Ahmad mendapat sebutan Kyai Jathilan, sebutan yang diterimanya dengan suka cita meski sebagian kelompok memandangnya secara (Dok. 3 Mei 2017).

Pesantren Al-Qodir ditempati oleh santri dari berbagai daerah seperti Jateng, DIY, Jawa Timur, Jawa Barat, Sumatera Selatan, Sumatera Utara, Kalimantan, Sulawesi, dan Papua. Berdasarkan data terbaru tahun 2017, santri Al-Qodir berjumlah 129 orang santri mukim (santri yang tinggal di pesantren) dan 300-an orang santri kalong (santri yang datang saat jam pelajaran) (Dok, 3 Mei 2017).

Keragaman dan keterbukaan pesantren Al-Qodir tersebut searah dengan visi pesantren, yakni mewujudkan Islam yang rahmatan Lil'alamin. Visi tersebut diperjelas melalui misinya, yakni mendidik santri dengan cara yang humanis atau memanusiakan manusia. Melalui visi dan misi tersebut, pesantren diharapkan dapat ikut mempengaruhi pola pemikiran santri dan masyarakat kearah positif baik dari segi spiritualitas, budaya, maupun ekonomi. Hal ini bisa terjadi karena pesantren tidak hanya mengajarkan ilmu-ilmu agama, tetapi juga membentuk usaha-usaha perekonomian dan berbagai keterampilan yang bisa menjadi bekal santri di kemudian hari (Dok. 3 Mei 2017).

Gambaran singkat tersebut secara tidak langsung menggambarkan adanya modal sosial yang penting. Disamping secara internal pesantren Al-Qodir ditempati oleh santri yang beragam, apa yang dilakukan pesantren dengan komunitas eksternal juga menunjukkan adanya respek yang tinggi terhadap keragaman. Keragaman tidak dianggap sebagai problem sosial, melainkan justru dianggap sebagai modal sosial. Dalam hal ini, hasil dan pembahasan penelitian akan dikaji secara sistematis, modal sosialmultikultural internal dan eksternal pesantren, serta tipe dan karakteristiknya dalam membangun harmoni sosial.

\section{Modal Sosial-Multikultural Internal Pesantren}

Pesantren Al-Qodir sebenarnya memiliki modal sosial-multikultural yang berasal dari internal institusinya sendiri. Modal ini bisa dimiliki karena para santri berasal dari berbagai daerah, mulai dari Jawa, Madura, Sunda, Sumatera, Kalimantan sampai Papua, dan tentu saja mereka memiliki latar belakang budaya yang beragam pula. Keragaman tersebut dipertemukan dalam wadah pesantren. Mereka bisa saling belajar untuk hidup bersama dalam waktu yang lama. Dengan demikian, keragaman santri tersebut merupakan modal pesantren yang penting dalam melakukan eksperimentasi hidup yang harmonis. Para santri tidak hanya mengenal keragaman pada setiap santri, melainkan mengalami secara langsung hidup bersama dalam keseharian pertemanan.

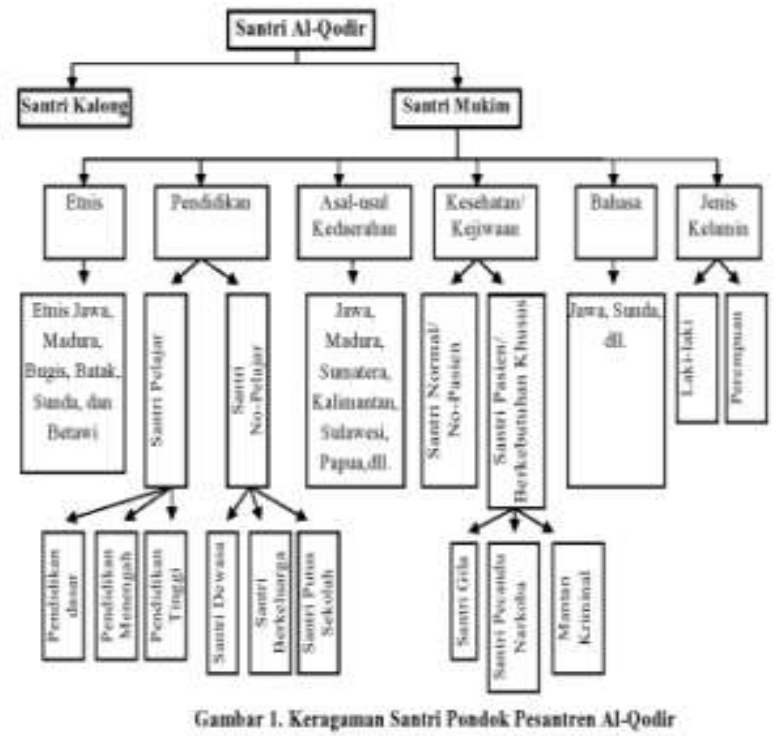


Di tengah keragaman asal usul kedaerahan dan budaya santri, pesantren ini ternyata unik karena terdapat kearagaman soal kejiwaan santri. Peneliti memiliki kesan tersendiri ketika menyaksikan santri gila (gangguan kejiwaan) hidup bersama dengan santri normal. Orang di luar pesantren yang pertamakali berkunjung ke pesantren ini bisa jadi tidak akan menduga jika yang ditemuinya terkadang orang gila. Orang gila ini tidak dibedakan kamarnya, melainkan membaur dalam satu asrama. Bahkan, terdapat beberapa kamar yang diisi tidak hanya santri biasa, tetapi juga santri gila dan mantan pecandu narkoba.

Relasi dan interaksi yang terbangun di antara santri yang beragam tersebut merupakan satu bentuk modal sosial multikultural yang paling nyata. Disamping bisa saling mengenal, mereka juga memiliki pengalaman multibudaya. Secara perlahan kesadaran akan keragaman santri akan tertanam dalam pribadi santri. Hampir tidak pernah terjadi unsur diskriminasi dan kekerasan di antara santri yang berbeda. Mereka sama-sama menyadari sebagai satu identitas santri atau kepesantrenan. Identitas kesantrian atau kepesantrenan tersebut mampu mengikat identitas kultural yang dibawa santri dari masingmasing daerahnya, sehingga secara tidak langsung membentuk budaya pesantren yang khas.

Kehidupan pesantren Al-Qodir yang didalamnya menyimpan modalitas keragaman tersebut bisa bertahan karena adanya nilai-nilai sosial-budaya pesantren yang kompatibel dengan keragaman. Nilai-nilai tersebut adalah kebersamaan, gotong royong, kekeluargaan, menghargai minat dan bakat, dan kebebasan.

\section{Kebersamaan}

Kebersamaan merupakan nilai yang melekat di pesantren Al-Qodir. Kebersamaan tidak hanya terjadi di ruang kamar tidur (tidur bersama), tetapi juga dalam kegiatan-kegiatan pesantren dan kegiatan sosial yang lain. Salah satu yang terkesan adalah soal giliran masak. Mereka diharapkan memiliki kesadaran sendiri untuk menyiapkan masakan. Mereka dibebaskan untuk makan apa saja yang tersedia di dapur pesantren. "Mau makan 2 kali, 3 kali, 10 kali bebas. Terserah santri tinggal mengambil sendiri di dapur (wawancara, 7 Juli 2018). Kebersamaan juga tampak dari aktivitas santri di luar pesantren. Ketika ada warga yang meninggal dunia, misalnya, para santri berbondong-bondong ke rumahnya. Para santri bersama-sama ikut mengurus jenazah dan mengantarkan ke pemakaman. Tentu saja masih banyak aktivitas di pesantren ini yang menunjukkan nilai kebersamaan.

\section{Gotong Royong}

Nilai kebersamaan di kalangan santri tersebut semakin diperkuat dengan nilai gotong royong. Gotong royong merupakan nilai budaya multikultural yang penting. Banyak hal yang dilakukan di pesantren dengan semangat gotong royong, seperti pembangunan gedung pesantren, bersih-bersih lingkungan, dan lainnya. Gotong royong yang dibangun di pesantren Al-Qodir juga berimplikasi terhadap gotong royong di masyarakat. Ketika masyarakat sedang membutuhkan, para santri banyak yang terlibat dalam kegiatan di masyarakat, seperti pembersihan saluran air, penataan irigasi di area persawahan, dan pembangunan jalan kampung.

\section{Kekeluargaan}

Karakteristik budaya pesantren AlQodir yang berkesan di hati para santri adalah nilai kekeluargaan. Mereka menganggap hidup di pesantren Al-Qodir seperti hidup dalam satu keluarga, dimana Kiai dan Bu Nyai sebagai bapak dan ibu mereka. Ikatan kekeluargaan tersebut ditampilkan melalui relasi santri dengan Kiai seperti halnya relasi anak 
dengan bapak. Santri Al-Qodir seringkali menyebut Kiai dengan sebutan "Bapak". Sebagaimana yang ungkapkan oleh salah satu informan, santri sini keluar-masuk ndalem. Di sini santri seperti anak sendiri. Intinya Kiai tidak ingin kelihatan Kiai. Di sini sudah dianggap keluarga sendiri. Seperti tidak ada sekat, tapi sebenarnya ada sekat. Di sini pokoknya Kiai di rumah, bebas menemui. Saya biasa panggilnya, bapak. Di sini kumpul jadi satu. Makan juga ikut Kiai. Kiai sudah kita anggap bapak sendiri (Wawancara, 8 Juli 2018).

Layaknya relasi antara anak dan bapak, apapun kebutuhan santri bisa dikonsultasikan dengan Kiai secara langsung. Untuk keperluan dapur, misalnya, Kiai Masrur seringkali menanyakan seputar kebutuhan dapur. Jika persediaan kebutuhan dapur menipis, Kiai segera memberikan uang untuk segera dibelikan kebutuhan dapur. Selain masalah kebutuhan pokok seharihari santri, selagi beliau ada di rumah, santri bisa langsung bertemu dan berbincang-bincang dengan Kiai.

\section{Saling menghargai minat dan bakat}

Hidup di pesantren Al-Qodir memang unik. Kegiatan santri sangat beragam; ada yang setiap harinya berternak, berkebun, supir, nambang pasir, tukang batu, dan sekolah. Meskipun minat dan bakat santri beragam, santri tidak diperbolehkan iri hati karena mereka melakukan kegiatan sesuai dengan minat dan bakatnya. Asal usul adanya keragaman kegiatan santri tersebut sebenarnya bukan berasal dari Kiai sepenuhnya. Seringkali pengadaan suatu kegiatan karena murni minat dan keinginan santri. Pengadaan truck tambang pasir, misalnya, bermula dari adanya keinginan santri memiliki pengalaman menjadi supir dan menambang pasir di sekitar lereng merapi. Adanya penyaluran minat dan kegiatan yang beragam tentu saja tidak boleh menganggu kewajibannya sebagai santri. Para santri umumnya memiliki kesadaran sendiri untuk menghentikan pekerjaannya jika waktunya shalat, mengaji, dan kegiatan pesantren lainya seperti mujahadah dan khataman setiap malam jumat.

\section{Kebebasan}

Kebebasan merupakan salah satu nilai yang menonjol di pesantren. Bebas dalam arti santri tidak dipaksakan untuk melakukan satu kegiatan tertentu. Bahkan, Kiai sendiri tidak pernah memaksa santri untuk mengikuti pengajian. Sebagaimana yang dituturkan, “... Saya ini tidak pernah memaksa. Tidak saya suruh begini-begitu. Dan saya juga tidak pernah menghukum. Saya hanya mencontoh keteladanan kanjeng Nabi Muhammad SAW. Sebisa mungkin prilaku saya ini menjadi contoh bagi santri-santri saya (wawancara, 7 Juli 2018).

Nilai kebebasan tersebut searah dengan konteks pesantren Al-Qodir yang diakui kebanyakan santri sebagai bengkel kehidupan. Hal ini menunjukkan bahwa pesantren Al-Qodir ditempati santri dengan berbagai latar belakang sosial. Ada yang gangguan jiwa, mantan narkoba, mantan kriminal, dan lainnya. Kenyatan ini membuat pesantren memiliki satu pandangan bahwa perubahan ke arah yang lebih baik memerlukan proses tidak cepat. Pandangan ini terutama harus disadari oleh para pengurus pesantren untuk tidak mengambil tindakan dan kebijakan yang dipukul rata. Setiap santri memiliki latar belakang yang beragam, sehingga kebijakan yang diambil juga beragam, sesuai dengan karakteristik individu santri.

\section{Modal Sosial-Multikultural Eksternal Pesantren}

Pesantren Al-Qodir dalam perkembangannya tidak hanya menjalin relasi dengan internal pesantren, tetapi juga berhubungan, berinteraksi, dan bekerjasama dengan berbagai komunitas 
di luar pesantren. Komunitas eksternal pesantren tersebut tidak hanya dari kalangan sesama pesantren atau sesama muslim, tetapi juga komunitas lintas budaya dan agama. Relasi ini juga bisa disebut sebagai jejaring multikultural.

Modal sosial-multikultural yang bersifat eksternal ini memiliki karakteristik tersendiri. Jejaring yang dibangun bukan hanya sekedar formalitas dengan perjanjian di atas kertas, melainkan keduanya saling berpartisipasi dan melakukan berbagai kegiatan secara bersama-sama. Ikatan kultural dan partisipasi tersebut bisa terjadi karena adanya trust atau kepercayaan di antara keduanya.

\section{Jejaring Multikultural}

Relasi pesantren dengan komunitas eksternal yang beragam menjadikan pesantren memiliki jejaring multikultural. Diantara jejaring multikultural yang dimiliki pesantren Al-Qodir bisa dikategorikan menjadi beberapa komunitas, yaitu:

Pertama, Komunitas Lintas Agama

Pesantren Al-Qodir seringkali menjalin hubungan dengan berbagai komunitas lintas agama. Diantara yang paling sering adalah hubungannya dengan Gereja Katholik St. Paulus \& Paulus Babadan. Hubungan tersebut terjalin sangat akrab, terutama antara Kiai Masrur dengan Romo Tri Widodo. Relasi personal juga berlanjut tidak hanya antar pemuka agama, tetapi juga antar anggota komunitas, antara anggota jamaah gereja dengan para santri. Hubungan tersebut diperkuat dengan penyelenggaraan kegiatan bersama seperti lomba, penampilan teater, pembuatan video, dan pembuatan film. Bahkan, saking akrabnya, para santri juga diberikan tempat khusus gratis secara gratis untuk menjual produk-produk santri ketika ada acara di gereja (wawancara, 9 maret 2019). Tidak hanya dengan Gereja Babadan, pesantren juga membangun jejaring dengan Gereja Katolik St. Fransiskus Xaverius Cangkringan. Salah satu bentuk respeknya, pesantren Al-Qodir pernah mengirimkan karangan bunga pada saat peresmian Gereja yang bertuliskan "Mahargyo Peresmian Gereja Katolik St. Fransiskus Xaverius Cangkringan, Pondok Pesantren Al-Qodir." Dalam peresmian tersebut, para santri berjumlah sekitar 30-an juga turut menampilkan hadrah selama 60 menit.

Dikalangan pemuda, para santri AlQodir juga sangat akrab dengan anakanak muda yang tergabung dalam organisasi Orang Muda Kaholik (OMK). Mereka seringkali berkomunikasi dan bekerjasama dalam berbagai kegiatan lintas agama. Tidak hanya mereka datang ke pesantren, para santri juga sering dapat undangan ketika mereka menyelenggarakan kegiatan (wawancara 9 Maret 2019). Pesantren Al-Qodir juga menjadi tempat Live In para siswa kelas $\mathrm{X}$ SMA Kolese de Brito Yogyakarta dalam program pendidikan toleransi. Selain itu, masih banyak komunitas lintas agama yang merupakan mitra kerjasama multikultural bagi pesantren Al-Qodir.

Melihat intensitas kegiatan multikultural di Al-Qodir, jejaring lintas agama tersebut sebenarnya sudah berjalan cukup lama. Jejaring ini bisa terbangun bermula dari pergaulan Kiai yang tidak hanya dengan internal muslim, melainkan dengan berbagai komunitas lintas agama. Relasi personal Kiai tersebut menjadi pintu awal untuk membuka relasi institusional pesantren.

Jejaring lintas agama tersebut ternyata memiliki keuntungan dan juga tantangan. Keuntugan paling nyata adalah terbukannya akses yang semakin luas, yang tidak hanya menyasar pada komunitas muslim, tetapi juga komunitas non-muslim. Di samping keuntungan tersebut, pesantren ini juga mendapat stigma negatif oleh sebagian kelompok. Oleh kelompok tertentu, Kiai kerap 
dijuluki sebagai Kiai kafir, Kiai sesat, dan sebutan negatif lainnya. Meski stigma ini bermunculan, pesantren tetap jalan terus sebagai bentuk tekad untuk menjaga komitmen perdamaian yang telah dibangun lama. Bahkan, oleh pesantren, siapapun boleh masuk ke pesantren, tanpa ada sekat-sekat teologis dan sosiologis. Bagi Kiai sendiri, semakin banyak tantangan justru dianggapnya semakin menikmati (Wawancara, 8 Juli 2018).

Kedua, Komunitas Sosial

Keterlibatan pesantren Al-Qodir dalam jejaring multikultural juga bisa dilihat dari bergabungnya pesantren dengan Konsorsium Penghijauan Area Lereng Merapi (PALM). Konsorsium tersebut merupakan gabungan berbagai perorangan, kelompok, instansi, ormas lintas iman, yang fokus untuk melakukan reboisasi/penghijauan di Lereng Merapi, khususnya Kecamatan Cangkringan, Sleman-DIY, menyusul adanya dampak Erupsi Merapi 2010. Banyak sekali yang terlibat dalam konsorsium ini seperti PWNU DIY, Paroki Babadan, Jaringan Gusdurian, Suster-suster Kongregasi CB, Fatayat NU, Perhimpunan Mahasiswa Islam Indonesia, Perhimpunan Mahasiswa Katolik Republik Indonesia, Bolo Tetulung, RS Panti Rapih, Yayasan Marsudi Rini, Kelompok Relawan Lereng Merapi, Sunda Wiwitan, Susteran PPYK Plunyon, Gerakan Jogja Bangkit, Forum Jalin Jogja, Lentera Anak Bangsa, dan beberapa kelompok lain yang bergabung (www.sustercb.com).

Dengan komunitas yang serupa, pesantren juga mendorong terbentuknya jejaring kerjasama dengan berbagai komunitas budaya dan agama, dalam kelompok Forum Silaturahmi Alim Ulama dan Tokoh Lintas Iman Sekitar Merapi (Forum Salaman Merapi). Kelompok ini beranggotakan beberapa tokoh agama Islam, tokoh lintas agama, dan budayawan dari beberapa daerah sekitar lereng Merapi, baik dari Yogyakarta,
Magelang, Klaten, dan Boyololali yang diketuai langsung oleh KH. Masrur Ahamad, pengasuh pesantren Al-Qodir. Tujuan utama dibentuknya forum ini adalah untuk menjadi mitra pemerintah dalam penanganan dampak bencana Merapi, sekaligus sebagai bentuk kontribusi persaudaran lintas agama dan budaya dalam kerja-kerja sosial. Beberapa rekomendasi juga disuguhkan. Salah satunya bahwa penataan kawasan harus didasarkan pada nilai-nilai keagamaan dan tradisi lokal.

Ketiga, Komunitas Lintas Seni-Budaya Tradisional

Jejaring lintas seni-budaya tradisional juga menjadi jejaring pesantren. Keberadaan komunitas ini bisa dibilang tidak biasa bagi kalangan pesantren. Sebagaimana yang disampaikan KH. Masrur Ahmad, "Karena umat saya, yang senang Jathilan, Ketoprakan, bukan mereka gak bisa ngaji. Akhirnya, saya membuat lomba Jathilan. Lomba Ketoprak. Mereka baru tahu, oh ternyata pesantren itu boleh dimasuki. Bukan saya yang mendoktrin... Saya cuma membuka pintunya. Terkadang mereka tidak hanya butuh ngaji, kadang juga butuh makan, ya saya kasih makan (Wawancara, 7 Juli 2018).

Selain jejaring tersebut sebagai bentuk akomodasi pesantren terhadap kesenian lokal, juga bisa dipahami sebagai modal penting bagi pembentukan harmoni sosial masyarakat. Para santri juga bisa melihat dan mengalami secara langsung adanya berbagai seni dan budaya lokal yang terdapat di masyarakat. Bentuk akomodasi semakin nyata dengan adanya perayaan yang diberi nama "Pesta rakyat Al-Qodir". Pesta tersebut adalah rangkaian kegiatan akhirussanah sebagai penutupan aktivitas pembelajaran pesantren selama setahun dan dilaksanakan pada akhir bulan Sya'ban sebelum memasuki bulan Ramadhan. 


\section{Social Trust Lintas Kultur}

Keterbukaan dan perluasan jejaring sosial lintas kultur tersebut diperkuat dengan adanya kepercayaan sosial (social trust). Kepercayaan sosial ini menjadi komponen penting dari modal sosialmultikultural yang dimiliki pesantren. Kepercayaan sosial ini bukanlah datang tiba-tiba, melainkan adanya upaya pesantren, khususnya Kiai, dalam menampilkan peran di tengah komunitas di luar pesantren yang sangat beragam. Kepercayaan tersebut diantaranya dibuktikan dengan respon, komunikasi, dan kegiatan yang dilakukan bersama.

Salah satu contoh bukti adanya kepercayaan tersebut adalah kunjungan rutin setiap tahun pada Program Bulan Pastoral. Dalam program ini, para pastor yang terdiri dari banyak Gereja mengunjungi pesantren dan berdialog dengan Kiai dan santri. Kepercayaan tersebut juga tidak datang secara tibatiba. Beberapa kali Kiai juga berusaha meyakinkan kepada kelompok lain bahwa pesantren Al-Qodir tidak membatasi diri bergaul dengan siapapun, sekalipun berbeda agama. Sebagaimana yang diungkapkannya, "saya juga bilang sama mereka. Jangan dianggap semua pesantren utu sama. Disini tidak masalah. Kalau kalian masuk ke pesantren lain. Jangankan masuk ke dalam, baru sampai gerbangnya sudah dilempar batu (Observasi, 7 Juli 2018).

Dalam membangun dan menjaga kepercayaan, pesantren terlebih dahulu menghilangkan prasangka-prasangka tidak baik kepada orang lain. Mengurangi prasangka menjadi langkah awal untuk bisa membuka diri. Mengurangi prasangka terlebih dahulu diawali dengan perasaan rendah hati, bahwa siapapun orangnnya bisa saja lebih baik dari yang dipersangkakan. Kepecayaan tidak harus diminta, melainkan pesantren lah yang terlebih dahulu membangun kepercayaan dengan memberikan kepercayaan dengan kelompok lain.
Konsep social trust pesantren nyaris tidak ada bedanya dengan konsep amanah dalam Islam. Dalam bukunya, Fukuyama mengartikan trust sebagai moralitas yang mendasari tingkat kepercayaan dalam suatu masyarakat. Masyarakat yang tingkat salingkepercayaanya rendah disebut Low Trust Society. Sebaliknya, masyarakat yang tingkat saling-kepercayaannya tinggi disebut High Trust Sociaty (Fukuyama).

Dalam terminologi Islam, Amanah merupakan ketundukan manusia terhadap seluruh dimensi pokok agama Islam karena melibatkan aspek vertical (hablumminallah) yakni beban pertanggungjawaban kepada Allah SWT dan aspek horizontal (hablumminannas) yaitu aspek syariah terutama dalam kaitannya dengan muamalah atau hubungan manusia dengan manusia dalam kehidupan bermasyarakat. Itulah sebabnya mengapa amanah menjadi salah satu substansi pokok agama Islam (Quraish Shihab).

Adanya beberapa modal sosialmultikultural pesantren tersebut sebenarnya juga memperlihatkan bahwa pesantren Al-Qodir merupakan tipe pendidikan Islam tanpa batas. Tipe ini dipertegas dengan slogannya, "pesantren Al-Qodir menembus batas". Slogan yang juga terpampang dalam profil pesantren di website tersebut ingin menegaskan bahwa pesantren ini ingin menghilangkan batas-batas kultural dan bahkan agama. Dalam menjalin relasi, pesantren tidak ingin dibatasi oleh sekat-sekat teologis, psikologis, dan sosiologis, sehingga ia terbuka berbagai individu, kelompok, maupun komunitas yang beragam.

Relasi multikultural tersebut membentuk satu modal sosial yang bisa disebut sebagai modal sosialmultikultural. Dikatakan modal sosialmultikultural karena modal sosial yang dimiliki dan dibangun pesantren tidak hanya bersumber dari internal pesantren dan komunitas muslim, melainkan juga 
dari beragam kultur dan agama yang beragam. Disatu sisi modal sosial tersebut dapat memperluas jangkauan modal sosial yang dimiliki pesantren, di sisi yang lain juga dapat berkontribusi bagi proses harmoni sosial bagi umat beragama.

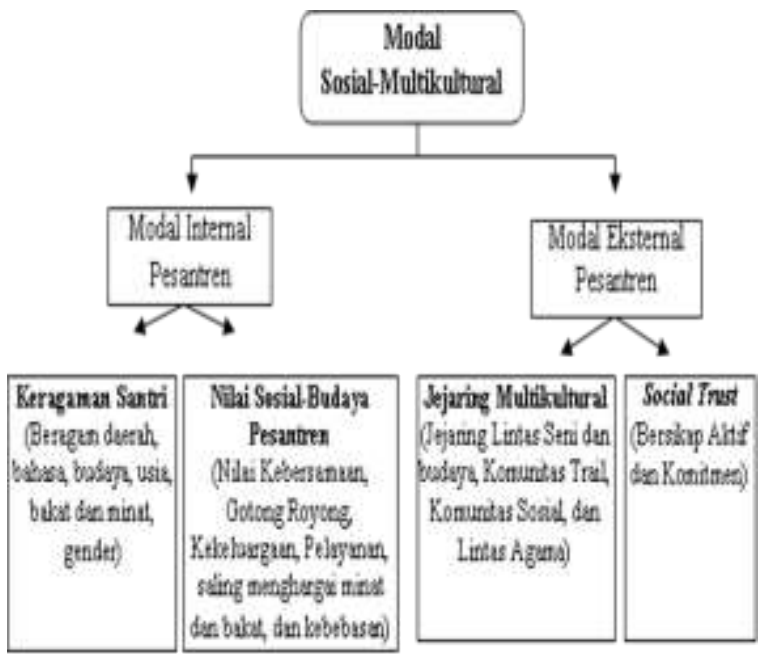

Gambar 2. Modal Sosial-Multikultural Pesantren Al-Qodir

\section{Tipe Modal Sosial-Multikultural Pesantren}

Modal sosial-multikultural di pesantren Al-Qodir menampilkan dua tipe, yakni bonding social-multicultural capital dan bridging social-multicultural capital. Modal sosial-multikultural dengan tipe bonding merupakan modal sosial dalam konteks ide, relasi dan perhatian yang berorientasi ke dalam (inward looking). Sedangkan, modal sosial dalam bentuk bridging bersifat inklusif dan berorientasi ke luar (outward looking). Tipe bonding menyatukan orang-orang satu sama lain dalam hal-hal penting (etnis, usia, jenis kelamin, kelas sosial, dan sebagainya), sedangkan bridging social capital mengacu pada jaringan sosial yang menyatukan orangorang yang tidak sama (Putnam).

Modal sosial multikultural pesantren pada tipe bonding bisa dilihat dari dua hal. Pertama, pesantren ditempati oleh santri yang berasal dari berbagai latar belakang yang beragam. Keragaman tersebut membentuk satu interaksi interkultural selama proses pendidikan di pesantren. Bahkan, hidup bersama (living with others/co-existance) merupakan bagian tidak terpisahkan dari kehidupan pesantren. Dengan beragam santri, maka pesantren adalah tempat bertemunya banyak tradisi, etnis, bahasa, dan budaya yang bisa dibagikan dan dikomunikasikan. Pada saat bersamaan, para santri juga memiliki kekayaan wawasan yang beragam.

Kedua, pesantren Al-Qodir tidak hanya memiliki modal sosialmultikultural yang bersumber dari internal pesantren. Pesantren juga bertemu, berdialog, dan bekerjasama dengan berbagai komunitas yang beragam di luar pesantren. Hal ini tidak hanya memperkuat dan memperkaya wawasan santri, tetapi juga pesantren perlu melibatkan diri dalam aksi-aksi multikultural di masyarakat. Beberapa jejaring sosial lintas agama dan budaya yang dibangun oleh kedua pesantren tersebut merupakan bagian dari keperluan ini.

Modal sosial yang kedua ini ternyata memberikan banyak keuntungan. Disamping perjumpaan dan kerjasama dengan beberapa komunitas beragam diluar pesantren bisa memberikan pengalaman belajar para santri, pesantren juga bisa memberikan kontribusi bagi persoalan-persoalan keragaman yang ada di masyarakat. Ini sekaligus dijadikan sebagai eksperimen bermasyarakat yang perlu diberikan kepada para santri agar dapat menumbuhkan kesadaran yang tinggi terhadap kerja-kerja sosial dalam konteks masyarakat yang multikultur. Terkait bridging social capital ini, ada dua komponen utama, yakni jejaring multikultural dan social trust.

\section{Pertama, Tipe Bonding}

Pesantren ditempati oleh santri yang berasal dari berbagai latar belakang yang beragam. Keragaman tersebut 
membentuk satu interaksi secara intercultural dalam setiap proses pendidikan sehari-hari. Bahkan, living with others (Co-Existance) merupakan bagian tidak terpisahkan dari kehidupan pesantren. Semakin beragam santri, semakin banyak tradisi, bahasa, dan budaya yang bisa dibagikan dan dikomunikasikan. Pada saat bersamaan, para santri memiliki kekayaan wawasan yang beragam.

Di tengah keragaman para santri tersebut, hampir tidak pernah dijumpai adanya clash atau gesekan yang terjadi di pesantren. Ini menunjukkan bahwa secara internal, pesantren Al-Qodir sebenarnya memiliki bangunan sosial lintas kultur yang bisa menjadi modal sosial. Modal sosial ini bisa menjadi kekuatan, terutama bagi para santri, dalam membangun kesadaran pentingnya menjaga harmoni sosial. Kesadaran ini akan terbangun dengan sendirinya melalui proses pembiasaan hidup dan saling belajar tentang nilai kebersamaan, gotong royong, kekeluargaan, kebebasan, dan saling menghargai minat dan bakat.

\section{Kedua, Tipe Bridging}

Melihat beberapa temuan di dua situs penelitian terkait modal sosial multikultural, terdapat tipe bridging social capital, yakni modal sosial yang bersifat inklusif dan berorientasi ke luar (outward looking). Ia mengacu pada jaringan sosial yang menyatukan orangorang yang tidak sama satu sama lain (Putnam). Pesantren juga memiliki tipe ini karena esantren juga bertemu, berdialog, dan bekerjasama dengan berbagai komunitas yang notabene memiliki perbedaan, baik dari segi agama maupun budaya. Tipe ini bisa dilihat pada jejaring multikultural dan social trust yang dibangun dan didayagunakan oleh pesantren.

Dikatakan jejaring multikultural, karena jejaring pesantren tidak hanya dengan komunitas pesantren, komunitas mulsim, dan komunitas internal umat
Islam lainnya (aliran keislaman, organisasi sosial islam, dll), tetapi komunitas eksternal lintas kultul dan agama. Jejaring tersebut menjadi jembatan penghubung antara dunia pesantren dengan komunitas masyarakat yang lebih luas. Hal ini juga memiliki kontribusi nyata bagi pembangunan harmoni sosial.

Setiap kegiatan yang diselenggarakan di pesantren dengan keterlibatan berbagai komunitas budaya dan agama tidak bisa lepas dari aspek social trust yang dimiliki oleh pesantren. kepercayaan tersebut secara tidak langsung terbangun melalui berbagai proses. Kepercayaan yang diberikan pesantren kaitannya dengan modal sosial-multikultural ditunjukkan dengan tangangungjawab dan perhatian yang besar terhadap komunitas-komunitas yang beragam.

\section{Karakteristik Modal Sosial-Multikultural Pesantren}

Jaringan sosial pesantren cenderung bersifat fleksibel, informal dan tidak kaku. Dalam menjalin hubungan lintas budaya dan agama, pesantren Al-Qodir cenderung lebih luwes dengan menempatkan unsur trust kepercayaan sebagai pegangan utama dan hal itu mengalir dan berjalan secara kultural, serta selalu dirawat dengan baik.

Pesantren Al-Qodir dalam mendayagunakan jejaring sosial juga tidak diorientasikan pada kerjasama yang saling menguntungkan secara ekonomi, melainkan karena dibangun berdasarkan keluwesan Kiai dan beberapa santri senior. Jika modal sosial memuat komponen pertukaran sosial di antara kedua belah pihak, maka pesantren AlQodir cenderung tidak memperhitungan untung rugi. Perhatian utama dalam membangun jejaring lintas kultur adalah semata-mata untuk kepentingan persaudaraan sebagai sesama manusia. 
$\begin{array}{clr}\text { Kebiasaan } & \text { dalam } & \text { menjalin } \\ \text { hubungan sosial } & \text { tersebut terutama }\end{array}$ karena tidak adanya pembatasan antara kehidupan pesantren dengan masyarakat. Antara santri dan masyarakat sekitar pesantren membaur, sehingga terbentuk satu kebiasaan dalam menjalin relasi dengan berbagai komunitas yang berbeda. hal ini menjadi modal utama dalam menambah keluwesan dalam bergaul. Keluwesan ini pada gilirannya memiliki jangkauan yang lebih luas.

Merujuk pada kajian yang dilakukan oleh Tim Paramadina (2004) yang terangkum dalam buku Fiqih Lintas Agama, ada satu kesinambungan antara toleransi, dialog dan kerjasama. Toleransi merupakan sikap yang menjadi titik berangkat terjadinya dialog dan kerjasama. Secara berurutan, dari toleransi ke dialog dan dari dialog ke kerjasama. Dengan demikian, ada benarnya jika modal sosial-multikultural juga mengandung sikap inklusif, toleransi, dialog, dan kerjasama. Pada saat bersamaan, dalam jejaring sosialmultikultural tersebut berlangsung suatu proses harmoni sosial.[]

\section{PENUTUP}

Modal sosial-multikultural yang terdapat di pesantren Al-Qodir memberikan satu paradigma bahwa keragaman merupakan aset/modal sosial yang berharga. Secara internal insitusi, pesantren memiliki banyak modal keragaman yang dibawa oleh para santri. Keragaman santri tersebut terbangun sistem sosial pesantren tersendiri yang memuat nilai dan norma. Nilai tersebut diantaranya nilai kebersa-maan, gotong royong, kekeluargaan, saling menghargai minat dan bakat, dan kebebasan. Dengan bangunan nilai tersebut, mereka dapat hidup secara harmoni.

Modal tersebut tidak hanya bersumber dari internal pesantren, tetapi juga bersumber dari lingkungan eksternal. Sumber tersebut berasal dari komunitas lintas agama, komunitas sosial, dan komunitas seni dan tradisi lokal. Sumber ini merupakan jejaring multikultural pesantren yang memiliki makna ganda. Disamping memperluas jangkauan relasi pesantren, adanya jejaring multikultural tersebut juga memperlihatkan adanya peran aktif pesantren dalam membangun relasi multikultural. Dalam banyak kegiatan yang dilakukan bersama komunitas multikultural, pesantren turut memberikan konstribusi nyata bagi harmonisasi sosial umat beragama.

\section{DAFTAR RUJUKAN}

B.Miles, Matthew, et al. "Qualitative Data Analysis-Matthew B. Miles, A. Michael Huberman, Johnny Saldaña Google Books." Sage Publications, 2014.

Bourdieu, Pierre. "Pierre Bourdieu 1986 The Forms of Capital." Handbook of Theory and Research for the Sociology of Education, 1986, pp. 241-58, doi:10.1002/9780470755679.ch15.

Di Fabio, Annamaria, and Akira Tsuda. "The psychology of harmony and harmonization: Advancing the perspectives for the psychology of sustainability and sustainable development." Sustainability 10.12 (2018): 4726.

Field, John. "Social Capital: Second Edition." Social Capital: Second Edition, vol. 9780203930519, 2008, doi:10.4324/9780203930519.

Fukuyama, Francis. Trust: The social virtues and the creation of prosperity. Vol. 99. New York: Free press, 1995.

Lestari, Sri, Maria Goretti Adiyanti Faturochman, and Bimo Walgito. "The Concept of Harmony in Javanese Society." Anima, Indonesian Psychology Journal 29.1 (2013): 2437.

Patton, Michael Quinn. Qualitative evaluation and research methods. 
SAGE Publications, inc, 1990. pp. 7374.

Putnam, Robert D. "Democracies in Flux : The Evolution of Social Capital in Contemporary Society Abstract and Keywords." Democracies in Flux, no. January 2012, 2002, pp. 1-27.

Quraish Shihab. "Wawasan Al-Qur'an Tafsir Tematik Atas Pelbagai Persoalan Umat." Pesan Al-Qur'an Dalam Ayat-Ayat Tentang Makanan, vol. 6, 2015, pp. 115-50.

Usman, Sunyoto. Modal Sosial. 1st ed., Pustaka Pelajar, 2018.

http://www.sustercb.com/konsorsiumpalm/. Diakeses pada hari Rabu tanggal 28 November 2018. 